\title{
Establishment of Critical Limits of Zinc in Soils Using Multi-extractants for Paddy Crop Grown in Central India
}

\author{
Rakesh Dhakad*, G. S. Tagore, B. L. Sharma, H. K. Rai and G. D. Sharma* \\ Department of Soil Science and Agricultural Chemistry, JNKVV, Jabalpur, \\ Madhya Pradesh, India \\ *Department of Soil Science and Agricultural Chemistry, College of Powarkeda, JNKVV, \\ Jabalpur Madhya Pradesh, India \\ *Corresponding author
}

\section{A B S T R A C T}

Field experiments were conducted during Kharif season 2015-16 at twenty farmer's field to refine the critical limit of Zinc in soils for rice crop grown in Mandla district of Madhya

\section{Keywords}

Zinc, Soils, Multi-extractants, Paddy crop, Central India

\section{Article Info}

Accepted:

08 January 2020

Available Online:

10 February 2020 Pradesh. The soils of study sites varied in available $\mathrm{Zn}$ from 0.12 to $2.17 \mathrm{mg} \mathrm{kg} \mathrm{gan}^{-1}$ classified in three groups i.e., deficient $\left(<0.60 \mathrm{mg} \mathrm{Zn} \mathrm{kg}^{-1}\right)$, marginal $(>0.60$ to $<1.2 \mathrm{mg} \mathrm{Zn}$ $\left.\mathrm{kg}^{-1}\right)$ and adequate $\left(>1.2 \mathrm{mg} \mathrm{Zn} \mathrm{kg}{ }^{-1}\right)$. The soils were clayey, neutral to slight alkaline in reaction and low in organic carbon. The $\mathrm{Zn}$ treatments $\left(0,2,4,6\right.$ and $8 \mathrm{~kg} \mathrm{Zn} \mathrm{ha}^{-1}$ through $\mathrm{ZnSO}_{4} 7 \mathrm{H}_{2} \mathrm{O}$ and $60 \mathrm{~kg} \mathrm{~N}, 60 \mathrm{~kg} \mathrm{P}_{2} \mathrm{O}_{5}$ and $40 \mathrm{~kg} \mathrm{~K} 2 \mathrm{O}$ through urea, single super phosphate (SSP) and muriate of potash, respectively were applied at the time of sowing in a factorial RBD and $60 \mathrm{~kg} \mathrm{~N} \mathrm{ha}^{-1}$ was applied at tillering stage. The rice MTU-1010 variety was sown @ $80 \mathrm{~kg} \mathrm{seed} \mathrm{ha}{ }^{-1}$ at $22.5 \mathrm{~cm}$ row to row spacing and harvested at maturity (120 DAS). The findings suggested that the increasing levels of $\mathrm{Zn}$ addition significantly increased the grain yield over control and optimum was at $6.0 \mathrm{~kg} \mathrm{Zn} \mathrm{ha}^{-1}$. The grain yield was identical at 6.0 and $8.0 \mathrm{~kg} \mathrm{Zn} \mathrm{ha}{ }^{-1}$. In field situation, the critical limit of $\mathrm{Zn}$ was calculated to be $0.62 \mathrm{mg} \mathrm{kg}^{-1}$ using Cate and Nelson statistical method and gave a predictability value of 53 per cent. Critical limits of $\mathrm{Zn}$ in soil for rice calculated to be $1.12 \mathrm{mg} \mathrm{kg}^{-1}$ by $\mathrm{NH}_{4} \mathrm{HCO}_{3}$ DTPA, $0.57 \mathrm{mg} \mathrm{kg}^{-1}$ by NH $4 \mathrm{OAC}, 0.88 \mathrm{mg} \mathrm{kg}^{-1}$ by EDTA $\left(\mathrm{NH}_{4}\right)_{2} \mathrm{CO}_{3}$ and $0.31 \mathrm{mg} \mathrm{kg}^{-1}$ by $0.05 \mathrm{~N} \mathrm{HCl}+0.025 \mathrm{~N} \mathrm{H}_{2} \mathrm{SO}_{4}$. Critical levels of $\mathrm{Zn}$ were found to be $12.7 \mathrm{mg} \mathrm{kg}^{-1}$ for paddy grain. In study area, paddy crop responded to $\mathrm{Zn}$ application. Hence, the application of $6 \mathrm{~kg} \mathrm{Zn} \mathrm{ha}^{-1}$ in soil through $\mathrm{ZnSO}_{4} 7 \mathrm{H}_{2} \mathrm{O}$ will enhance the productivity of rice.

\section{Introduction}

Rice is one of the most important global staple food crops and is a primary food source for more than one third of the global population (Prasad et al., 2010). Nutritionally, the grain comprises $80 \%$ starch, $7.5 \%$ protein,
$0.5 \%$ ash and $12 \%$ water. In Asia, India has the largest area under rice cultivation (44.3 million ha) accounting for 29.4 per cent of the global rice area. Though the productivity level in India is low $\left(2.04 \mathrm{t} \mathrm{ha}^{-1}\right)$ as compared to Japan (6.25 t ha $\left.{ }^{-1}\right)$, China $\left(6.24 \mathrm{t} \mathrm{ha}^{-1}\right)$ and Indonesia $\left(4.25 \mathrm{tha}^{-1}\right)$ which can be attributed 
to either insufficient fertilizer use or imbalanced fertilization and are strongly related with nutrient depletions (Chaudhary et al., 2007).

Zinc is one of the essential plant micronutrient and its importance for crop productivity is similar to that of major nutrients (Rattan et al., 2009). Zinc is required for large number of enzymes and plays an essential role in DNA transcription. It is a constituent of several enzymes with role in carbohydrate and protein synthesis, maintaining the integrity of membranes, regulating auxin synthesis and in pollen formation. Zinc leads to the formation of indole acetic acid from tryptophane, which is found in plants and in the activity of dehydropeptidase and glycoglycine dipeptidase, which play a specific role in the protein metabolism.

It is required by rice in small quantity, but its deficiency has an adverse effect on healthy crop growth and yield may be reduced up to 30 percent. Almost $50 \%$ of the world soils in cereal growing areas are $\mathrm{Zn}$ deficient (Gibbson, 2006). In India 49\% soils are potentially deficient in Zn (Singh, 2008), while $60 \%$ soils in Madhya Pradesh were found $\mathrm{Zn}$ deficient (Shukla and Tiwari 2016). Availability of $\mathrm{Zn}$ in soils for plants is a function of soil properties. Zinc fertilizers are used for the prevention of $\mathrm{Zn}$ deficiency and biofortification of cereal grains (Alloway, 2009). Zn use efficiency is hardly 1 to 5\%. Imbalanced, blanket use and inadequate use of chemical fertilizers in intensive cropping systems is the main cause for stagnation in productivity, insecurity in food and environmental hazards. Under deficient condition the crops are likely to respond more to application of zinc.

Critical levels means a level below which the crops will readily respond to its application. This level varies with crops, soil and the extractants used. Zinc application is usually made on the basis of the soil fertility class, thus the crop response to added $\mathrm{Zn}$ is not always obtained (Rahman et al., 2007). Critical zinc for rice was $(0.74 \pm 0.18 \mathrm{mg}$ $\mathrm{kg}^{-1}$ ) across the soils and agro-ecological regions of India (Rattan et al., 2008). The critical limits are quite often employed for a wide variety of soils and crops, even though these critical limits may be different not only for soils, crop species but also for different varieties of a given crop (Singh and Agrawal, 2007). Soils with DTPA-Zn less than critical limit gave $82.7 \%$ more yield when $\mathrm{Zn}$ was applied at $5 \mathrm{mg} \mathrm{kg}^{-1}$ and soils with DTPA-Zn more than critical limit recorded only $34.8 \%$ yield increase in Meghalaya soils (Singh et al., 1999).

The general critical limit of $\mathrm{Zn}$ in soil and crops fall in the range of $0.6-1.0 \mathrm{mg} \mathrm{kg}{ }^{-1}$ (DTPA-extractable) and $10-20 \mathrm{mg} \mathrm{kg}^{-1}$ in dry matter respectively (Katyal and Rattan, 2003) but it vary with soils and crops. For clear prediction of possible deficiencies, their critical limits must be refined with reference to the soil and crop characteristics, respectively as they vary in their $\mathrm{Zn}$ supplying capacity and use efficiency. In earlier, most of the studies of critical limits have been conducted in pot, which are entirely different than field conditions. In study area where of rice is predominant and intensively cultivated and critical limit for zinc has not been fixed so far. Therefore, the present investigation was undertaken under field condition to refine the critical limit of zinc in soil for rice for making $\mathrm{Zn}$ application more rational.

\section{Materials and Methods}

\section{Description of study area}

Geographically, the Mandla district is located in the east-central part of the Madhya Pradesh covering an area of $8771 \mathrm{sq} \mathrm{km}$ and consists of a rugged high tableland in the eastern part 
of the Satpura hills. Thus the climate of this district is characterized by hot summer season and general dryness except in the southwest monsoon season. May is the hottest month with the mean daily minimum temperature at $41.3{ }^{0} \mathrm{C}$ and the mean daily minimum at 24 ${ }^{0} \mathrm{C}$. Paddy, Maize, Kodo and Kutki is an important crops during Kharif season and Wheat, Pea, Chickpea, Lentil and Mustard crops during Rabi season in tribal areas of district.

Zinc status and distribution in soil of different villages of Mandla district

\section{Survey, collection of soil samples for selecting sites}

Seventy five surface soil samples $(0-15 \mathrm{~cm})$ were collected from different tribal villages (Bilnagari Mal, Bhvera Mal, Chikhali and Chargaon Kalan) of Bijadandi block of Mandla district in Madhya Pradesh, India (Table-1 and Fig-1).

\section{Selection of sites for experimentation}

The initial soil samples were analysed for available zinc (0.005 M DTPA) as given in table-1 indicated that the soil $\mathrm{pH}$ varied from 5.40 to 7.80 with a mean value of 6.73 . The organic carbon content of soil samples ranged from 3.0 to $9.20 \mathrm{~g} \mathrm{~kg}^{-1}$ with a mean value of $6.01 \mathrm{~g} \mathrm{~kg}^{-1}$. In general, soils were low to medium in organic carbon content and more than 25 per cent soils were found low in organic carbon. The available $\mathrm{N}, \mathrm{P}$ and $\mathrm{K}$ status of soils ranged from 145 to $410 \mathrm{~kg} \mathrm{ha}^{-1}$; 7.0 to $31.80 \mathrm{~kg} \mathrm{ha}^{-1}$ and 150 to $614 \mathrm{~kg} \mathrm{ha}^{-1}$ with a mean value of $298.50 \mathrm{~kg} \mathrm{ha}^{-1} ; 15.14$ $\mathrm{kg} \mathrm{ha}^{-1}$ and $320.30 \mathrm{~kg} \mathrm{ha}^{-1}$, respectively. The value of $\mathrm{S}$ was ranged from 1.61 to $31.63 \mathrm{mg}$ $\mathrm{kg}^{-1}$ with a mean value of $15.95 \mathrm{mg} \mathrm{kg}^{-1}$. The results are in agreement with earlier work of Tagore et al., (2015). The DTPA-extractable $\mathrm{Zn}$ ranged from 0.21 to $2.17 \mathrm{mg} \mathrm{kg}$. Variations in soil $\mathrm{pH}$, lime, organic matter amount of phosphorus and zinc can significantly affect the $\mathrm{Zn}$ bioavailability (Adiloglu and Adiloglu, 2006).

\section{Details of the experimentation}

Field experiments were conducted during Kharif season 2015-16 at twenty farmer's field to find out the effect of $\mathrm{Zn}$ levels $(0.0$, 2.0, 4.0, 6.0 and $8.0 \mathrm{~kg} \mathrm{Zn} \mathrm{ha}^{-1}$ ) on yield, $\mathrm{Zn}$ content and their uptake by rice grown on selected sites with standard agronomic practices. The soils of study sites varied in available $\mathrm{Zn}$ from 0.12 to $2.17 \mathrm{mg} \mathrm{kg}^{-1}$ and classified in three groups i.e., deficient $(<0.60$ $\mathrm{mg} \mathrm{Zn} \mathrm{kg}{ }^{-1}$ ), marginal ( $>0.60$ to $<1.2 \mathrm{mg} \mathrm{Zn}$ $\mathrm{kg}^{-1}$ ) and adequate $\left(>1.2 \mathrm{mg} \mathrm{Zn} \mathrm{kg}^{-1}\right)$.

The soils are clayey, neutral to slight alkaline in reaction and low to medium in organic carbon. The $\mathrm{Zn}$ treatments $(0,2,4,6$ and $8 \mathrm{~kg}$ $\mathrm{Zn} \mathrm{ha}^{-1}$ through $\mathrm{ZnSO}_{4} 7 \mathrm{H}_{2} \mathrm{O}$ ) were applied at the time of sowing in a factorial randomised block design. The basal dose of $60 \mathrm{~kg} \mathrm{~N}, 60$ $\mathrm{kg} \mathrm{P}_{2} \mathrm{O}_{5}$ and $40 \mathrm{~kg} \mathrm{~K} \mathrm{~K}_{2} \mathrm{O}$ were applied through urea, single super phosphate (SSP) and muriate of potash respectively at the time of sowing and $60 \mathrm{~kg} \mathrm{~N} \mathrm{ha}{ }^{-1}$ was applied at tillering stage. The rice MTU-1010 variety was sown @ $80 \mathrm{~kg} \mathrm{ha}^{-1}$ at $22.5 \mathrm{~cm}$ row to row spacing and harvested at maturity (120 DAS).

\section{Soil sample preparation and their chemical analysis}

From each experimental site, representative surface $(0-15 \mathrm{~cm})$ soil samples were collected before and after harvest of rice crop. The experimental soil $(0-15 \mathrm{~cm}$ depth) samples were air dried and crushed with wooden pestle and mortar and sieved through $2 \mathrm{~mm}$ sieve. Initial and post harvest data thus obtained are given in Table-1. Organic carbon of the soil was analyzed by Walkley and Black (1934) method. Soil pH was measured in soil: water: (1:2.5) suspension. Electrical conductivity was determined by following 
standard protocol (Jackson, 1973). Macronutrients were analsyed using standard method described by (Jackson 1973). Available zinc content in soil samples was extracted with $0.005 \mathrm{M}$ DTPA (Diethylene triaminepenta acetic acid) -TEA (pH 7.3) in 1:2 ratio (Soil: Extractant) following the method of Lindsay and Norvell (1978) and the concentration of $\mathrm{Zn}$ in the extracted solution was estimated with the help of Atomic Absorption Spectrophotometer (AAS).

\section{Chemical analysis of plant samples}

Grain and straw yield from each plot were recorded and grain and straw samples were analyzed for $\mathrm{Zn}$ content. The plant samples were digested in a di-acid mixture of nitric and perchloric acid (4:1) and $\mathrm{Zn}$ content in digestate was determined using Atomic Absorption Spectrophotometer. The uptake was estimated by multiplying the $\mathrm{Zn}$ content in grain and straw with their yield.

\section{Estimation of critical limit}

For establishing the critical limit of available Zn (DTPA extractable) the method of Cate and Nelson (1971) was used. The Bray's per cent yield was calculated as per the formula given in Bray's percent Yield =Yield without zinc/ Optimum yield with zinc $x$ 100. In the graphical version, horizontal and vertical lines were positioned to maximise number of points in the first and third quadrant to obtain the critical value. This was verified statistically from the total variance $\left(\mathrm{R}^{2}\right)$ of observed values with postulated critical values, where the $\mathrm{R}^{2}$ peaks at the critical value.

\section{Results and Discussion}

Considering critical value of $\mathrm{Zn}$ in soils $(0.60$ $\mathrm{mg} \mathrm{kg}{ }^{-1}$ ), 45, 30 and 25 percent soils were grouped into deficient, marginal and adequate classes, respectively (Table-2). Grain and straw yield of paddy significantly increased with the application of 2, 4, 6 and $8 \mathrm{~kg} \mathrm{Zn} \mathrm{ha}^{-1}$ over control (RDF). The maximum yield of grain and straw was recorded with $8 \mathrm{~kg} \mathrm{Zn} \mathrm{ha}^{-}$ application, which was at par to $6 \mathrm{~kg} \mathrm{Zn} \mathrm{ha}^{-1}$ as soil application. The variations in yield of rice in different soils were due to difference in ability of soils to supply zinc to the crop. Data revealed that the response in grain yield per cent with increasing levels of applied $\mathrm{Zn}$ in soils ranged from $11.12(\mathrm{~S}-12)$ to $76.26(\mathrm{~S}-13)$ per cent. However, at higher $\mathrm{Zn}$ levels (6.0 and $8.0 \mathrm{~kg} \mathrm{Zn} \mathrm{ha}^{-1}$ ) the response was not much more over RDF.

The positive effect of $\mathrm{Zn}$ might be due to its beneficial effect on metabolism (Rashid and Fox 1992). Naik and Das (2010) reported that the application of zinc to low land rice soil of West Bengal resulted the $37.8 \%$ and $20.9 \%$ increase in grain and straw yield of rice, respectively over the control. Significant yield increase was observed by Muthukumararaja and Sriramachandrasekharan (2012) when an application of 5 and $7.5 \mathrm{mg} \mathrm{Zn} \mathrm{kg}{ }^{-1}$ was done in a soil with DTPA-Zn $0.86 \mathrm{mg} \mathrm{kg}^{-1}$ in India. Fageria et al., 2011 reported DMY increase to occur in an Inceptisol after applying $5 \mathrm{mg} \mathrm{Zn}$ $\mathrm{kg}^{-1}$. Kandali et al., 2014 reported a significant increase in straw yield when 4.2 $\mathrm{mg} \mathrm{Zn} \mathrm{ha}{ }^{-1}$ was applied in a soil with DTPA$\mathrm{Zn} 0.55 \mathrm{mg} \mathrm{Zn} \mathrm{kg}^{-1}$. The lack of response of plants grown in the six soils is justified by Dobermann and Fairhust (2000) who concluded that soils with zinc above $0.8 \mathrm{mg}$ $\mathrm{Zn} \mathrm{kg}$ were not expected to give any response. Other researchers, Fageria et al., 2011 reported a no significant effect between 5 and $120 \mathrm{mg} \mathrm{Zn} \mathrm{kg}^{-1}$ rates when $\mathrm{Zn}$ was applied in an acidic soil with $1.4 \mathrm{mg} \mathrm{Zn} \mathrm{kg}^{-1}$ which supports the no yield increase in the treatments that received 5 and $10 \mathrm{mg} \mathrm{Zn} \mathrm{kg}^{-1}$ application rates. 
Table.1 Details of experimental sites and initial fertility status

\begin{tabular}{|c|c|c|c|c|c|c|c|c|c|c|c|c|}
\hline ID & Name of farmers & Location & $\begin{array}{c}\text { Lat } \\
\text { (DD) }\end{array}$ & $\begin{array}{l}\text { Long } \\
\text { (DD) }\end{array}$ & $\begin{array}{c}\mathrm{Zn} \\
\left(\mathrm{mgkg}^{-1}\right)\end{array}$ & pH & $\begin{array}{c}\mathrm{EC} \\
\left(\mathrm{dSm}^{-1}\right)\end{array}$ & $\begin{array}{c}\mathrm{OC} \\
\left(\mathrm{g} \mathrm{kg}^{-1}\right)\end{array}$ & $\begin{array}{c}\mathrm{N} \\
\left(\mathrm{kgha}^{-1}\right)\end{array}$ & $\begin{array}{c}\text { P } \\
\left(\text { kgha }^{-1}\right)\end{array}$ & $\begin{array}{c}\text { K } \\
\left(\mathrm{kgha}^{-1}\right)\end{array}$ & $\begin{array}{c}\mathrm{S} \\
\left(\mathrm{mgkg}^{-1}\right)\end{array}$ \\
\hline 1 & Shri Suresh Kumar & Chikhali & 23.07156 & 80.22461 & 2.17 & 6.50 & 0.14 & 3.90 & 188.00 & 9.00 & 485.00 & 4.72 \\
\hline 2 & Shri Gariba marko & Chikhali & 23.07672 & 80.21856 & 0.12 & 6.90 & 0.27 & 5.70 & 275.00 & 15.30 & 340.00 & 30.07 \\
\hline 3 & Shri Bhuvan lal & Chikhali & 23.07064 & 80.24361 & 0.43 & 6.50 & 0.12 & 9.20 & 410.00 & 31.80 & 205.00 & 30.46 \\
\hline 4 & Shri Roop Singh 1 & Chargaon kala & 23.07361 & 80.22867 & 0.90 & 7.00 & 0.05 & 5.60 & 267.00 & 11.40 & 250.00 & 31.63 \\
\hline 5 & Shri Indar Singh & Poniya mal & 23.07167 & 80.24598 & 0.47 & 7.70 & 0.41 & 6.20 & 296.00 & 29.40 & 280.00 & 5.21 \\
\hline 6 & Shri Pohat Singh Yadav & Bhavera Raiyat & 23.07444 & 80.2265 & 1.00 & 6.30 & 0.08 & 6.20 & 296.00 & 7.10 & 250.00 & 8.05 \\
\hline 7 & Shri Shankar lal & Bhavera Raiyat & 23.07775 & 80.23525 & 0.15 & 5.40 & 0.13 & 4.90 & 332.00 & 22.30 & 384.00 & 12.50 \\
\hline 8 & Shri Tilak Singh & Bhavera Raiyat & 23.06956 & 80.24883 & 0.34 & 6.40 & 0.18 & 8.10 & 389.00 & 12.90 & 614.00 & 17.78 \\
\hline 9 & Shri Javahar singh & Bhavera Raiyat & 23.08783 & 80.24067 & 0.22 & 6.90 & 0.26 & 4.20 & 346.00 & 15.70 & 207.00 & 16.53 \\
\hline 10 & Shri Nokhelal & Bhavera Raiyat & 23.07042 & 80.24656 & 0.51 & 6.80 & 0.36 & 3.00 & 145.00 & 15.70 & 587.00 & 12.84 \\
\hline 11 & Shri Tibari Singh & Chargaon kala & 23.07464 & 80.22389 & 1.07 & 7.30 & 0.06 & 6.50 & 310.00 & 10.60 & 212.00 & 9.41 \\
\hline 12 & Shri Hunkar Singh & Chargaon kala & 23.07342 & 80.22361 & 1.27 & 6.50 & 0.09 & 7.20 & 346.00 & 7.40 & 184.00 & 12.15 \\
\hline 13 & Shri Gyanprasad & Chargaon kala & 23.06683 & 80.22806 & 1.43 & 7.60 & 0.12 & 7.40 & 354.00 & 18.40 & 230.00 & 14.06 \\
\hline 14 & Shri Ramlakhan shahu & Chargaon kala & 23.08653 & 80.23378 & 0.27 & 6.90 & 0.15 & 7.70 & 368.00 & 11.40 & 457.00 & 24.37 \\
\hline 15 & Shri Roop Singh 2 & Chargaon kala & 23.07042 & 80.25581 & 0.32 & 6.40 & 0.27 & 5.00 & 239.00 & 19.20 & 211.00 & 20.68 \\
\hline 16 & Shri Rampal & Chargaon kala & 23.06942 & 80.22606 & 1.66 & 7.80 & 0.24 & 5.00 & 239.00 & 11.40 & 411.00 & 14.41 \\
\hline 17 & Shri Ashok Singh & Bilnagari mal & 23.06889 & 80.22639 & 1.83 & 6.20 & 0.16 & 4.20 & 203.00 & 20.40 & 273.00 & 18.14 \\
\hline 18 & Shri Bhagavat Singh & Bilnagari mal & 23.08556 & 80.244 & 0.61 & 6.30 & 0.13 & 4.50 & 217.00 & 12.50 & 375.00 & 26.06 \\
\hline 19 & Shri Keshav lal & Bilnagari mal & 23.09189 & 80.24183 & 0.71 & 6.30 & 0.10 & 7.70 & 368.00 & 10.60 & 150.00 & 1.61 \\
\hline 20 & Shri Ashok Singh & Bilnagari mal & 23.07778 & 80.24464 & 0.83 & 6.80 & 0.17 & 8.00 & 382.00 & 10.20 & 301.00 & 8.39 \\
\hline \multicolumn{5}{|c|}{ Minimum } & 0.12 & 5.40 & 0.05 & 3.00 & 145.00 & 7.10 & 150.00 & 1.61 \\
\hline \multicolumn{5}{|c|}{ Maximum } & 2.17 & 7.80 & 0.41 & 9.20 & 410.00 & 31.80 & 614.00 & 31.63 \\
\hline \multicolumn{5}{|c|}{ Mean } & 0.82 & 6.73 & 0.17 & 6.01 & 298.50 & 15.14 & 320.30 & 15.95 \\
\hline
\end{tabular}


Table.2 Summary of chemical extractants used to determine available soil micronutrients

\begin{tabular}{|c|l|c|c|l|}
\hline $\begin{array}{c}\text { S. } \\
\text { No. }\end{array}$ & \multicolumn{1}{|c|}{ Extractants } & $\begin{array}{c}\text { Soil: Solu. } \\
\text { Ratio }\end{array}$ & $\begin{array}{c}\text { Shaking } \\
\text { period }\end{array}$ & \multicolumn{1}{|c|}{ Reference } \\
\hline $\mathbf{1}$ & $\begin{array}{l}0.005 \mathrm{M} \mathrm{DTPA}- \\
\mathrm{CaCl}_{2}(\mathrm{pH} 7.3)\end{array}$ & $1: 2$ & 2 hours & Lindsay and Norvell (1978) \\
\hline $\mathbf{2}$ & $\begin{array}{l}1 \mathrm{M} \mathrm{NH} \mathrm{HCO}_{3}+0.005 \mathrm{M} \\
\mathrm{DTPA}(\mathrm{pH} \mathrm{7.6})\end{array}$ & $1: 2$ & 15 minutes & $\begin{array}{l}\text { Soltanpour and Schwab } \\
(1977)\end{array}$ \\
\hline $\mathbf{3}$ & $\begin{array}{l}0.01 \mathrm{M} \mathrm{EDTA}+1 \mathrm{M} \\
\left(\mathrm{NH}_{4}\right)_{2} \mathrm{CO}_{3}(\mathrm{pH} 7.0)\end{array}$ & $1: 2$ & 30 minutes & Trieweiler and Lindsay(1969) \\
\hline $\mathbf{4}$ & $\begin{array}{l}1 \mathrm{~N} \mathrm{CH}_{3} \mathrm{COO} \cdot \mathrm{NH}_{4} \\
(\mathrm{pH} \mathrm{6.8})\end{array}$ & $1: 20$ & 2 hours & Lyman and Dean (1942) \\
\hline $\mathbf{5}$ & $\begin{array}{l}0.05 \mathrm{NCl}+0.025 \mathrm{~N} \\
\mathrm{H}_{2} \mathrm{SO}_{4}(6.5)\end{array}$ & $1: 5$ & 30 minutes & Mehlich-1 (1953) \\
\hline
\end{tabular}

Table.3 Response of Zn application on yield at optimum dose of Zn $6.0 \mathrm{~kg} \mathrm{Zn} \mathrm{ha}^{-1}$

\begin{tabular}{|c|c|c|c|c|c|c|c|}
\hline \multirow[t]{2}{*}{ Soil } & \multirow{2}{*}{$\begin{array}{c}\text { DTPA } \\
\text { extractable } \\
\text { Zn (mgkg- } \\
\left.{ }_{1}\right)\end{array}$} & \multicolumn{3}{|c|}{ Grain yield $\left(\mathrm{t} \mathrm{ha}^{-1}\right)$} & \multicolumn{3}{|c|}{ Straw yield $\left(\mathrm{t} \mathrm{ha}^{-1}\right)$} \\
\hline & & Zn- & $\mathbf{Z n}+$ & Res. (\%) & Zn- & $\mathbf{Z n}+$ & Res. (\%) \\
\hline S-1 & 0.47 & 2.19 & 2.54 & 15.98 & 5.49 & 7.48 & 36.20 \\
\hline S-2 & 0.12 & 1.93 & 2.39 & 23.83 & 3.84 & 5.25 & 36.60 \\
\hline S-3 & 1.00 & 2.28 & 3.00 & 31.39 & 4.67 & 5.92 & 26.70 \\
\hline S-4 & 0.90 & 2.70 & 3.40 & 25.96 & 5.14 & 7.17 & 39.47 \\
\hline S-5 & 2.17 & 2.06 & 3.11 & 50.73 & 4.41 & 6.03 & 36.84 \\
\hline S-6 & 0.43 & 2.28 & 2.69 & 17.66 & 5.46 & 7.30 & 33.68 \\
\hline S-7 & 1.27 & 2.34 & 3.22 & 37.41 & 6.40 & 8.54 & 33.32 \\
\hline S-8 & 0.34 & 2.18 & 2.90 & 32.82 & 4.93 & 6.11 & 23.95 \\
\hline S-9 & 0.22 & 3.95 & 5.01 & 26.92 & 8.02 & 9.07 & 13.14 \\
\hline S-10 & 0.71 & 2.91 & 4.77 & 64.03 & 5.25 & 7.81 & 48.70 \\
\hline S-11 & 0.27 & 2.36 & 2.99 & 27.02 & 7.26 & 8.45 & 16.49 \\
\hline S-12 & 0.51 & 2.70 & 3.00 & 11.12 & 7.41 & 9.35 & 26.14 \\
\hline S-13 & 1.43 & 2.31 & 4.07 & 76.26 & 8.19 & 9.81 & 19.78 \\
\hline S-14 & 1.07 & 3.16 & 5.10 & 61.56 & 7.69 & 9.97 & 29.55 \\
\hline S-15 & 0.32 & 2.61 & 3.35 & 28.22 & 4.28 & 6.32 & 47.55 \\
\hline S-16 & 0.61 & 3.06 & 3.43 & 11.86 & 4.97 & 6.71 & 34.94 \\
\hline S-17 & 1.83 & 1.79 & 2.81 & 56.98 & 4.95 & 6.71 & 35.53 \\
\hline S-18 & 1.66 & 2.33 & 3.40 & 45.78 & 4.34 & 7.11 & 63.62 \\
\hline S-19 & 0.15 & 2.49 & 3.02 & 21.42 & 4.74 & 7.35 & 55.04 \\
\hline S-20 & 0.63 & 2.57 & 3.64 & 41.76 & 5.13 & 6.71 & 30.80 \\
\hline
\end{tabular}


Fig.1 Location of experiments

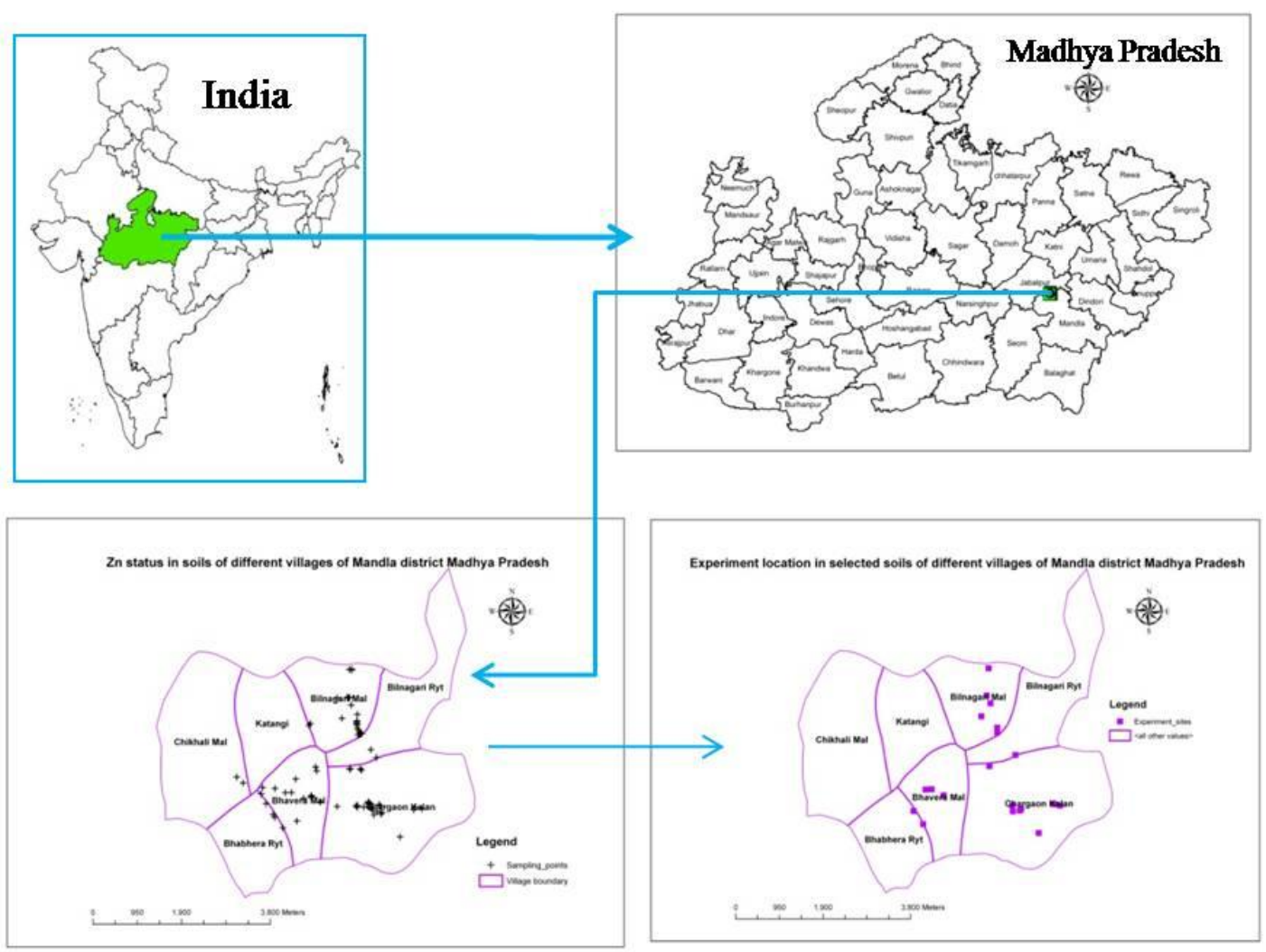

Fig.2

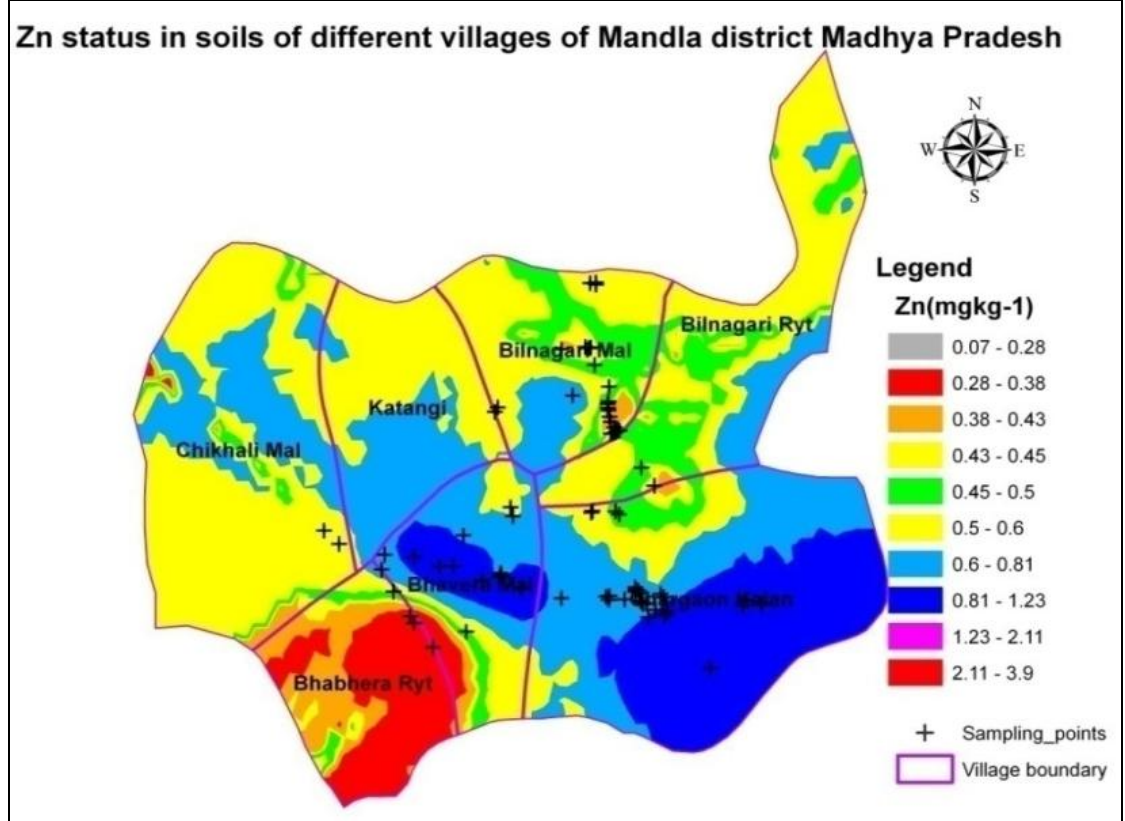


Fig.3.1 to 3.5 scattered diagram for critical limits of $\mathrm{Zn}$ in soil for paddy grown in soils of Mandla district using different extract ants and Fig. 3.6 to 3.7 scattered diagram for critical limits of $\mathrm{Zn}$ in rice grain and shoot of paddy.

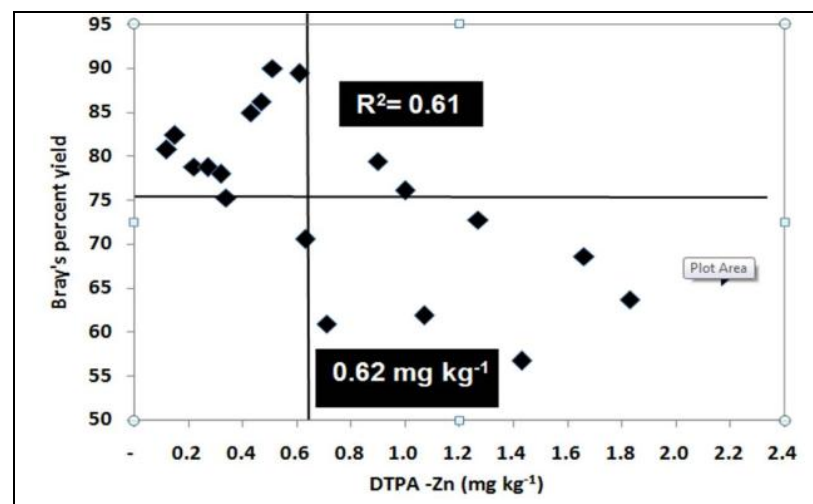

Fig. 3.1: Relationship of Bray's percent yield of rice with DTPA extractable zinc in soil

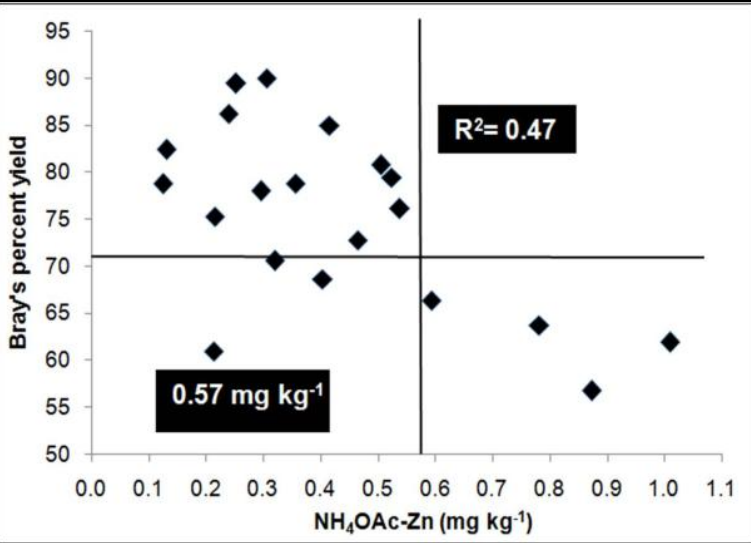

Fig3.3: Relationship of Bray's percent yield of rice with $\mathrm{NH}_{4} \mathrm{OAc}$ extractable zinc in soil

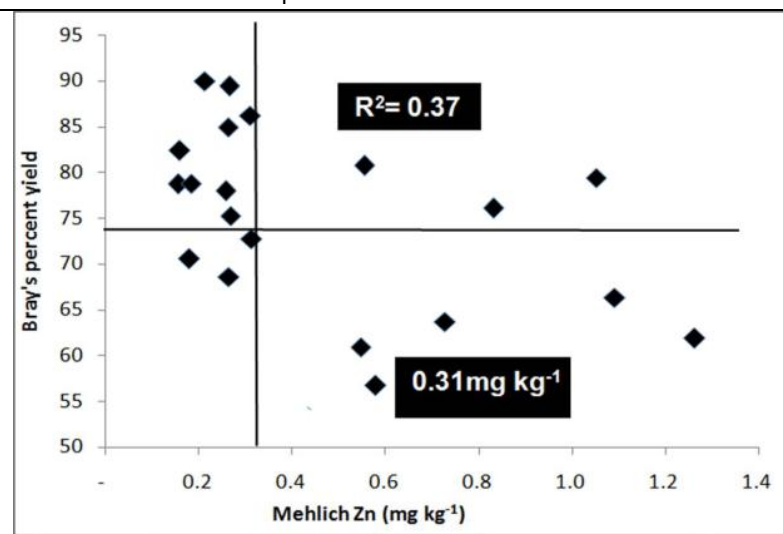

Fig 3.5: Relationship of Bray's percent yield of rice with Mehlich-1 extractable zinc in soil

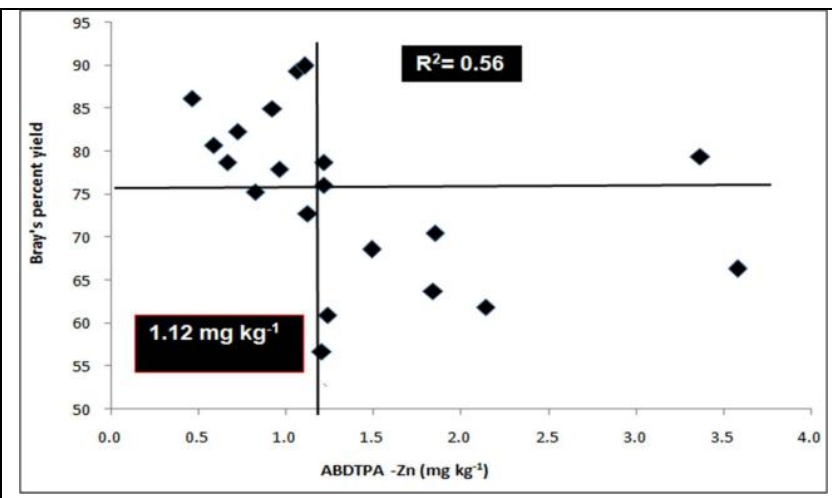

Fig 3.2: Relationship of Bray's percent yield of rice with $\mathrm{NH}_{4} \mathrm{HCO}_{3}$-DTPA extractable zinc in soil

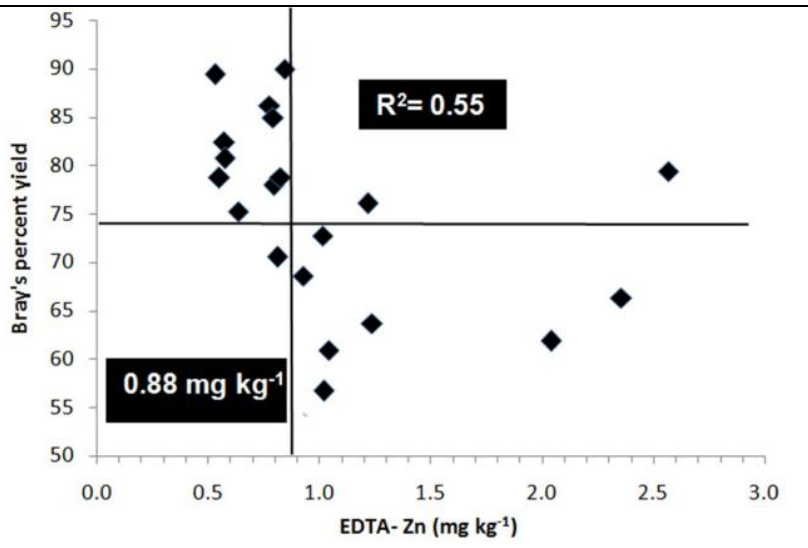

Fig 3.4: Relationship of Bray's percent yield of rice with $\left(\mathrm{NH}_{4}\right)_{2} \mathrm{CO}_{3}$ extractable zinc in soil

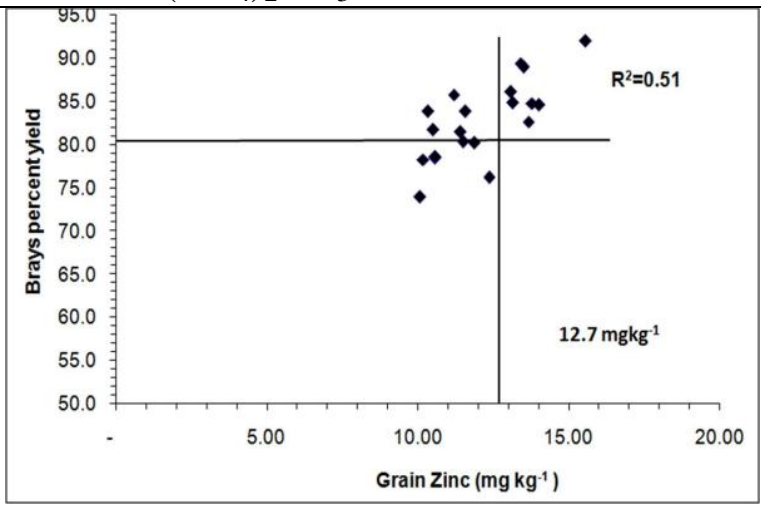

Fig.3.6: B Relationship of Bray's percent yield with zinc concentration in rice grain 


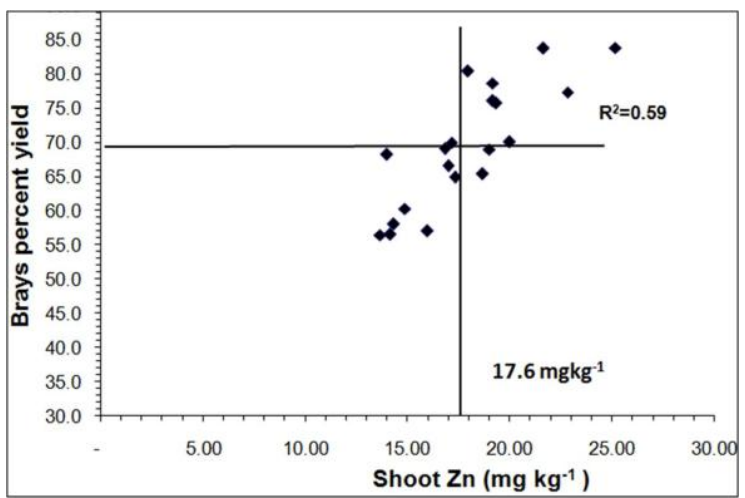

Fig.3.7: B Relationship of Bray's percent yield with zinc concentration in shoot of rice

Rasavel and Ravichandran (2012) observed a similar trend in an alkali soil with DTPA-Zn of $0.21 \mathrm{mg} \mathrm{kg}^{-1}$ at Tamil Nadu, India. The grain yield increase can be explained by the fact that $\mathrm{Zn}$ controls enzymes related to reproduction (Rahman et al., 2007, Fageria et al., 2011). The decrease in yield due to application of $\mathrm{Zn}$ at $10 \mathrm{mg} \mathrm{Zn} \mathrm{kg}^{-1}$ suggests that $\mathrm{Zn}$ may approach the toxic levels when high rate of $\mathrm{Zn}$ is applied in soils with $\mathrm{Zn}$ above $3.0 \mathrm{mg} \mathrm{kg}^{-1}$ in soil. Sakal et al., 1982 reported yield decrease when 5 and $10 \mathrm{mg} \mathrm{Zn}$ $\mathrm{kg}^{-1}$ were applied in calcareous soil with high levels of $\mathrm{Zn}$.

Critical limits of $\mathrm{Zn}$ in soil for paddy grown in Mandla district using different extract ants

The DTPA- $\mathrm{CaCl}_{2}$ extractable zinc was highly correlated as it gave maximum values of correlation coefficients with Bray's per cent yield $(\mathrm{r}=0.539 * *)$ and $\mathrm{Zn}$ uptake $(\mathrm{r}=0.533 * *)$. The amount of zinc extracted by $\mathrm{NH}_{4} \mathrm{HCO}_{3}$ DTPA was also correlated significantly with Bray's yield $\left(\mathrm{r}=0.445^{* *}\right)$ and $\mathrm{Zn}$ uptake $\left(\mathrm{r}=0.503^{* *}\right)$ by rice crop. Further, the relationships between zinc extracted by ammonium acetate and $\mathrm{Zn}$ uptake $\left(\mathrm{r}=0.483^{*}\right)$ was found significant. Similarly EDTA$\left(\mathrm{NH}_{4}\right)_{2} \mathrm{CO}_{3}$ extractable zinc and Mehlich-1 correlated with Bray's yield and zinc uptake by rice crop but non-significant.
The scatter diagrams for Bray's yield versus soil zinc by different methods are presented in (Fig.3.1 to 3.5). Critical limits were calculated to be $0.62 \mathrm{mgkg}^{-1}$ by DTPA-CaCl $2,1.12 \mathrm{mg}$ $\mathrm{kg}^{-1}$ by $\mathrm{NH}_{4} \mathrm{HCO}_{3}$ DTPA, $0.57 \mathrm{mg} \mathrm{kg}^{-1}$ by $\mathrm{NH}_{4} \mathrm{OAC}, 0.88 \mathrm{mg} \mathrm{kg}^{-1}$ by EDTA $\left(\mathrm{NH}_{4}\right)_{2} \mathrm{CO}_{3}$ and $0.31 \mathrm{mg} \mathrm{kg}^{-1}$ by $0.05 \mathrm{~N} \mathrm{HCl}+0.025 \mathrm{~N}$ $\mathrm{H}_{2} \mathrm{SO}_{4}$. These values are close to critical level of $\mathrm{Zn}$ for soils $\left(0.83 \mathrm{mg} \mathrm{kg}^{-1}\right)$ as observed by Rahman et al., (2007), Muthukumararaja et al., (2012). Result showed the critical levels of $\mathrm{Zn}$ were found to be $12.7 \mathrm{mg} \mathrm{kg}^{-1}$ for rice grain (Fig 3.6). However, critical limit of DTPA-extracted $\mathrm{Zn}$ and plant $\mathrm{Zn}$ was 0.76 $\mathrm{mg} \mathrm{kg}{ }^{-1}$ soil and $21.5 \mathrm{mg} \mathrm{kg}^{-1}$ reported by Sakal et al., (1984) for rice in Sub-Himalayan hill and forest soils of India. The critical limits of $\mathrm{Zn}$ in plants indicates deficiency as suggested by Dobermann et al., (2000) are :< $10 \mathrm{mg} \mathrm{kg}{ }^{-1}$ definite $\mathrm{Zn}$ deficiency, $10-15 \mathrm{mg}$ $\mathrm{kg}^{-1}$ very likely, $15-20 \mathrm{mg} \mathrm{kg}^{-1}$ likely and $>20$ $\mathrm{mg} \mathrm{kg}^{-1}$ unlikely (sufficient). In most crop species leaf sufficiency range for $\mathrm{Zn} 15$ to 50 $\mathrm{mgkg}^{-1}$ in the dry matter of mature plants and in most cases $15 \mathrm{mgkg}^{-1} \mathrm{Zn}$ is considered as critical value (Benton, 2003). For better $\mathrm{Zn}$ nutrition of human being, cereals grains should contain around 40-60 mg $\mathrm{Zn} \mathrm{kg}$; however the current situation is 10 to $30 \mathrm{mg}$ $\mathrm{kg}^{-1} \mathrm{Zn}$ (Cakmak 2008). Dobermann and Fairhust (2000). They suggested that zinc concentration in rice tissues between 10 to 20 $\mathrm{mg} \mathrm{kg}^{-1}$ as deficient. This phenomenon was 
expected since these soils had low levels of $\mathrm{Zn}$ concentration and resulted in plants with relatively low grain yields which were accompanied with low $\mathrm{Zn}$ concentration in the $\mathrm{Zn}$ without treatment. The critical concentration of $\mathrm{Zn}$ in rice shoots was approximated to be $17.6 \mathrm{mg} \mathrm{kg}^{-1}$ (Fig-3.7). This critical concentration is close to the lower level of the optimum range of $25-50 \mathrm{mg}$ $\mathrm{kg}^{-1}$ reported by Dobermann and Fairhust (2000) as well as the lower level of the sufficiency range of $20-160 \mathrm{mg} \mathrm{kg}^{-1}$ reported by Campbell 2000.

It is concluded that in study area, the critical limit of $\mathrm{Zn}$ was analysed to be $0.62 \mathrm{mg} \mathrm{kg}^{-1}$ for rice in field situation, hence, paddy crop will be responded to $6 \mathrm{~kg} \mathrm{Zn} \mathrm{ha}{ }^{-1}$ in soil through $\mathrm{ZnSO}_{4} 7 \mathrm{H}_{2} \mathrm{O}$.

\section{Acknowledgement}

The authors of manuscript wish to acknowledge JNKVV, Jabalpur, Madhya Pradesh and AICRP on MSN ICAR for providing facility for conducting the work.

\section{References}

Adiloglu A and Adiloglu S (2006) The effect of boron (B) application on the growth and nutrient contents of maize in zinc $(\mathrm{Zn})$ deficient soils. Res. J. Agric. Bio. Sci., 2, 14.

Alloway BJ (2009) Soil factors associated with zinc deficiency in crops and humans. Environ. Geochem. Health., 31, 537-548.

Benton JJ (2003) Agronomic handbook; management of crops, soils and their fertility. CRC press LLC. USA.

Cakmak, I (2008) Enrichment of cereal grains with zinc. Agronomic or genetic bio fortification? Plant Soil., 302, 1-17.

Campbell CR (2000) Reference sufficiency ranges for plant analysis in the Southern region of the United States. Southern Cooperative Series No 13. 134.

Cate R B and Nelson L A (1971) A simple statistical procedure for partitioning soil test correlation data into two classes. Soil Science Society of America Proceedings 35, 658-660.

Chaudhary SK, Thakur SK, Pandey AK (2007) Response of wetland rice to nitrogen and zinc. Oryza 44(1):31-34.

Dobermann A, Fairhust T (2000) Rice nutrient disorders and nutrient and nutrient management. International Rice Research Institute. Potash and Phosphate Institute, of Canada, and International Rice Research Institute, Singapore and Los Baños.;203.

Fageria NK, Dos Santos AB, Cobucci T (2011) Zinc nutrition of lowland rice. Commun Soil Sci Plant Analy. 42(14):1719-1727.

Gibbson RS (2006) Zinc: The missing link in combating micronutrient malnutrition in developing countries. Proceedings of the Nutrition Society, University of East Anglia, Norwich, June 28 - July 1, 2005.

Jackson ML (1973) Soil Chemical Analysis. Prentice Hall of India Pvt. Ltd., New Delhi, 498.

Kandali GG, Basumatary A, Barua NG, Medhi BK, Hazarika S (2014) Response of rice to zinc application in acidic soils of Assam. Annals of Plant and Soil Res.; 17(1):74-76.

Katyal JC and Rattan RK (2003) Secondary and micronutrients: Research gaps and future needs. Fertiliser News 48:9-14, 17-20.

Lindsay WL and Norvell, WA (1978) Development of DTPA soil test for Zn, Fe, $\mathrm{Mn}$ and $\mathrm{Cu}$. Soil Sci. Soci. American J., 42: 421-428.

Lyman C and Dean LA (1942) Zinc deficiency of pineapples in relation to soil plant composition. Soil Science 54:315.

Mehlich A (1953) Determination of P, Ca, Mg, K, $\mathrm{Na}$, and NH4. North Carolina Soil Test Division (Mimeo, 1953).

Muthukumararaja $\mathrm{T}$ and Sriramachandrasekharan MV (2012). Critical limit of zinc for rice soils of Veeranam command area, Tamil Nadu, India. ARPN J. Agril. and Bio. Sci., 7: 22-33.

Muthukumararaja TM and Sriramachandrasekharan MV (2012) Effect of zinc on yield, zinc nutrition and zinc use efficiency of lowland rice. J Agr Techn.8:551-561. 
Prasad R, Prasad, LC and Agrawal RK (2010). Genetic diversity in Indian germplasm of aromatic rice. Oryza 46: 197-201.

Rahman MA, Jahiruddin M and Islam MR (2007) Critical limit of zinc for rice in calcareous soils. J. of Agric. Rural Dev., 5: 47-47.

Rasavel M, Ravichandran M (2012) Effect of zinc phosphorus and sulphur interactions on growth and yield of rice under neutral and alkali soils. Inter $\mathrm{J}$ Mater Sci Chem. 1(1):12-14

Rashid A and Fox RL (1992) Evaluating internal zinc requirements of grain crops by seed analysis. J. Agron., 84: 469-474.

Rattan RK, Patel KP, Manjaiah KM and Datta, SP (2009). Micronutrients in soil, plant animal and human health. J. Indian Soc. Soil Sci., 57: 546-558.

Rattan RK, SP Datta and JC Katyal (2008) Micronutrient management-research achievements and future challenges. Indian J. Fert. 4: 93-106.

Sakal R, Singh AP, Singh BP and Sinha RB (1984) Assessment of some chemical extractants for available zinc in relation to response of rice to applied zinc in SubHimalayan Hill and forest soils. Plant and Soil. 79: 417-428.

Sakal R, Singh BP, Singh AP (1982) Determination of critical limit of zinc in soil and plant for predicting response of rice to zinc application in calcareous soils. Plant and Soil. 6(1):129-132.

Shukla AK and Tiwari PK (2016) Progress report 2014-16 on All India Coordinated Research Project on Micro and Secondary Nutrients and Pollutant elements in soils and plants,
IIISS, Bhopal.

Singh AK, Manibhushan, Meena MK, Upadhyaya MA (2012) Effect of sulphur and zinc on rice performance and nutrient dynamics in plants and soil of Indo Gangetic Plains. J. Agr. Sci. 4(10):162-170.

Singh AK, Nongkynrih P and SK Khan (1999) Critical limit of zinc deficiency for predicting response of rice soils of Meghalaya. J. Indian Soc. Soil Sci. 47: 567-569.

Singh VK and Agarawal HP (2007) Development of Dris norms for evaluating, nitrogen, phosphorus potassium and sulphur requirements of rice crop. J. Indian Soc. Soil Sci., 55: pp. 294-303.

Singh, MV (2008) Micronutrient deficiencies in crops and soils in India. In: Alloway, B. (ed). Micronutrient deficiencies in global crop production. Springer, Dordrecht, pp. 93-126.

Soltanpour PN and Schwab, AP (1977) A new soil test for simultaneous extraction of macro and micronutrients in alkaline soils. Communication in Soil Science and Plant Analysis, 8: 195-207.

Trierweiler, JF and Lindsay WL (1969) EDTA ammonium carbonate soil test for zinc. Soil Sci. Soc.Amer.Proc. 33: 49-54.

Zare M, Khoshgoftarmanesh AH, Norouzi M, Schulin R (2009) Critical soil zinc deficiency concentration and tissue iron: Zinc ratio as a diagnostic tool for prediction of zinc deficiency in corn. J Plant Nutr. 32(12):1983-1993.

\section{How to cite this article:}

Rakesh Dhakad, G. S. Tagore, B. L. Sharma, H. K. Rai and Sharma, G. D. 2020. Establishment of Critical Limits of Zinc in Soils Using Multi-extractants for Paddy Crop Grown in Central India. Int.J.Curr.Microbiol.App.Sci. 9(02): 1270-1280.

doi: https://doi.org/10.20546/ijcmas.2020.902.150 